\title{
STABLE ISOTOPE ANALYSIS ON BALEEN WHALES (SUBORDER: MYSTICETI): A REVIEW UNTIL 2017
}

Lucas Milmann ${ }^{1,2}$, Larissa Rosa de Oliveira' ${ }^{2,3}$, Ian M. Danilevicz ${ }^{4}$, Ana Paula Madeira Di Beneditto ${ }^{5}$, Silvina Botta $^{6}$, Salvatore Siciliano ${ }^{7,8}$, Julio Baumgarten ${ }^{2}$.

${ }^{1}$ Grupo de Estudos de Mamíferos Aquáticos do Rio Grande do Sul (GEMARS). Rua Bento Gonçalves, 165, sala 1002, Bairro Centro. Torres, RS, Brazil.

${ }^{2}$ Applied Ecology and Conservation Lab. Programa de Pós-graduação em Ecologia e Conservação da Biodiversidade. Departamento de Ciências Biológicas. Universidade Estadual de Santa Cruz (UESC). Rodovia Jorge Amado, km 16, Ilhéus, BA, Brazil.

${ }^{3}$ Laboratório de Ecologia de Mamíferos, Universidade do Vale do Rio dos Sinos (UNISINOS), Avenida Unisinos, 950, São Leopoldo - RS, Brazil.

${ }^{4}$ Programa de Pós-graduação em Estatística. Universidade Federal de Minas Gerais (UFMG). Av. Antônio Carlos, 6627, Belo Horizonte - MG, Brazil

${ }^{5}$ Universidade Estadual do Norte Fluminense Darcy Ribeiro (UENF). Laboratório de Ciências Ambientais (LCA). Av. Alberto Lamego, 2000, Campos dos Goytacazes, RJ, Brazil.

${ }^{6}$ Laboratório de Ecologia e Conservação da Megafauna Marinha (ECOMEGA), Instituto de Oceanografia,

Universidade Federal do Rio Grande - FURG, Avenida Itália km8 s/n, Rio Grande - RS, Brazil

${ }^{7}$ Laboratório de Biodiversidade, Instituto Oswaldo Cruz/Fiocruz, Rio de Janeiro, RJ, Brazil.

${ }^{8}$ Grupo de Estudos de Mamíferos Aquáticos da Amazônia (GEMAM), Museu Paraense Emílio Goeldi, Belém, PA, Brazil

Corresponding Author: Lucas Milmann, Doutor em Ecologia, lcmilmann@gmail.com

\section{RESUMO}

A análise de isótopos estáveis (AIE) fornece informações sobre a produtividade do oceano e aspectos ecológicos de baleias relacionados ao uso do habitat e ecologia alimentar, estrutura de estoque, fisiologia e evolução. Foram revisados estudos publicados usando a AIE em baleias em todo o mundo entre novembro de 1979 e junho de 2017. Foram avaliadas lacunas nas áreas geográficas e heterogeneidade entre as espécies estudadas usando essa metodologia. Também investigamos quais tecidos foram mais utilizados para análise, as fontes de variação em valores de isótopos estáveis, a combinação desta metodologia com outras técnicas e como pode ser útil para a conservação deste táxon e dos ecossistemas marinhos. Um total de 63 publicações foi encontrado e foi possível detectar aumento no número de publicações, uma vez que $49 \%$ dos estudos foram realizados nos últimos 7 anos e meio do período analisado. Quase $55 \%$ dos estudos concentraram-se na ecologia de forrageio e no uso do habitat. As cerdas bucais foram o principal tecido analisado. Os estudos investigaram 14 espécies, sendo mais comuns aqueles relacionados a baleia-fin, Balaenoptera physalus $(\mathrm{N}=19)$ e a baleia-da-Groenlândia, Balaena mysticetus $(\mathrm{N}=18)$. As metodologias de telemetria e AIE combinadas foram úteis para entender as variações geográficas em valores de isótopos estáveis. A metodologia pode também ter valor no cenário de mudanças climáticas fornecendo informações sobre plasticidade alimentar e amplitude de nicho de diferentes espécies, por exemplo. Apesar das incertezas relacionadas à distribuição dos valores de isótopos estáveis no mar e às taxas de incorporação em baleias, por exemplo, a AIE fornece informações ecológicas primordiais para o manejo e conservação desse grupo.

Palavras chave: Balaenopteridae, Balaenidae, Análise de Isótopos Estáveis, Ecologia da Conservação.

\section{ABSTRACT}

Stable Isotope Analysis (SIA) has provided information on ocean productivity, and ecological aspects related to whales' habitat use and feeding ecology, stock structure, physiology, and evolution. We reviewed published studies using SIA on whales worldwide from November 1979 to June 2017. Gaps in geographical areas and heterogeneity amongst species studied using this methodology were assessed. We also investigated which tissue was most frequently analysed, sources of variation in stable isotope values, how this methodology has been combined with other techniques, and how it can be useful for the conservation of the taxon and marine ecosystems. A total of 63 publications were found, and it was possible to detect a general increase in the number of publications along time, as $49 \%$ of the studies were from the last 7.5 years of the period analyzed. Almost $55 \%$ of studies focused on foraging ecology and habitat use. The baleen plate was the main tissue analyzed. Studies were related to 14 species, the most common being the fin whale, Balaenoptera physalus $(\mathrm{N}=19)$ and the bowhead whale, Balaena mysticetus $(\mathrm{N}=18)$. Telemetry and SIA methodologies combined were helpful to understand geographical variations in stable isotope values. The methodology can also be valuable under the current scenario of climate change, for example providing information on feeding plasticity and changes in niche amplitude of different species. Despite uncertainties related with stable isotopes distribution in the ocean, and with its incorporation rates for whales, for example, SIA provides primordial ecological information for efficient management and conservation of this group. Key words: Balaenopteridae, Balaenidae, Stable Isotopes Analysis, Conservation Ecology. 


\section{INTRODUCTION}

Baleen whales (Suborder: Mysticeti) have been impacted by commercial hunting activities (e.g. Clapham and Baker 2002, Morais et al. 2016), and some populations remain critically endangered after the official banning of whaling in 1986 by a moratorium from the International Whaling Commission (Thomas et al. 2015). Among the threatened species are the blue whale (Balaenoptera musculus) and the sei whale (Balaenoptera borealis) (Cooke 2018), while the North Atlantic right whale (Eubalaena glacialis) is critically endangered. Additionally, there are several species that are still data deficient, such as the Omura's whale (Balaenoptera omurai) (Cooke and Brownell Jr. 2019, Cooke 2020). Besides past pressures and lack of knowledge regarding some species of the group, there are new challenges for those whales such as anthropogenic ocean noise (Weilgart 2007), collision with ships (Laist et al. 2001), and climate change that may alter availability of resources (Learmonth et al. 2006).

Baleen whales have keratinous baleen plates which are efficient for bulk filter-feeding on schooling fish, squid, and zooplankton (Croll et al. 2009). They usually grow fast for young individuals when compared to adults (Schell et al. 1989, Best and Schell 1996), and can be especially interesting for the analysis of long-term registers related to the diet of the individuals being investigated (e.g. CaraveoPatiño et al. 2007). Baleen plate growth rates have been estimated based on SIA, ranging between $\sim 12.9$ to $\sim 20 \mathrm{~cm} /$ year for Balaenopteridae species such as common minke (Balaenoptera acutorostrata), fin (Balaenoptera physalus) and blue whales (Giménez et al. 2003, Mitani et al. 2006, Bentaleb et al. 2011, Aguilar et al. 2014, Busquets-Vass et al. 2017), and $\sim 26 \mathrm{~cm} /$ year for Balaenidae species such as bowhead (Balaena mysticetus) and southern right whales (Eubalaena australis) (Schell et al. 1989, Best and Schell 1996). Therefore, this structure is suitable for SIA, contributing for ecological studies of whales (e.g. Schell et al. 1989, Bentaleb et al. 2011, Borrel et al. 2012).

The chronological patterns of stable isotopes deposition in baleen plates has been used to provide information on migratory cycles and dispersion (e.g. Caraveo-Patiño and Soto 2005, Roubira et al. 2015), trophic level (e.g. Shoeninger and DeNiro 1984, Davenport and Bax 2002, Das et al. 2003), feeding ecology and growth patterns (e.g. Caraveo-Patiño et al. 2007), stock discrimination (e.g. Giménez et al. 2013), increase in the concentration of radiocarbon $\left({ }^{14} \mathrm{C}\right)$ due to nuclear tests (e.g. Schell et al. 1989b), and different contaminant concentrations in aquatic food webs (e.g. Van de Vijver et al. 2003, Roubira et al. 2015). Moreover, patterns in stable isotopes on baleen plates have been used to verify temporal changes in carbon isotope ratios in Bering/Chukchi sea zooplankton (2000) (Schell 2001a). SIA has also been used to verify variabilities in average seasonal primary productivity due to anthropogenic input of carbon dioxide in the atmosphere, with findings showing a decrease of $30-40 \%$ in such productivity (Schell 2001b). Furthermore, the use of SIA for the investigation of aspects including individual movement patterns across multi-year timescales provides important information for the effective management and conservation of the group and the ocean environment (Busquets-Vass et al. 2017). The most common elements analyzed are carbon, nitrogen, and oxygen, but sulphur $(\mathrm{S})$ and lead $(\mathrm{Pb})$ have also been used to study baleen whales (Hoekstra et al. 2002, Roubira et al. 2015).

External or environmental sources of variation in stable isotopes, such as sources of water or nutrients (e.g. nitrogen) availability, need to be considered for interpretation of baseline (e.g., primary producers) values (Ostrom and Fry 1993, Fry 2006). Once these variations are comprehended, results can provide a base for interpretation of trophic structure and consequently the trophic level of different species (e.g. Ostrom et al. 1993). Also, global patterns of isotope values for primary producers in marine environments have broad ranges. That is mainly due to differences in the isotopic composition of inorganic nutrient sources, the type of nutrient available (e.g. $\mathrm{NO}_{3}^{-}, \mathrm{NH}_{4}^{+}, \mathrm{N}_{2}$ ) and their concentration, the primary producer species composition and growth rates, as well as the magnitude of discrimination against the heavy isotope during nutrient uptake and subsequent fixation (Ostrom and Fry 1993, Troina et al. 2020). Such spatial variation in stable isotope values have been described as marine isoscapes (West et al. 2010, McMahon et al. 2013, Magozzi et al. 2017, Troina et al.2020), which are useful to study the movement and dietary patterns of baleen whales over ocean-basin scales (Killingley 1980, Busquets-Vass et al. 2017). Stable isotopes grids have been created based on stable isotope values of plankton sampled worldwide 
(e.g. Rau et al. 1982, Graham et al. 2010, McMahon et al. 2013, Troina et al. 2020). The carbon isotope ratios can be aligned with ecological divisions within aquatic systems, where inshore basal sources tend to have higher $\delta^{13} \mathrm{C}$ values when compared with offshore regions and similarly, benthic sources have higher $\delta^{13} \mathrm{C}$ values when compared with pelagic sources (Rubenstein and Hobson 2004, Fry 2006). In this context, studies of marine animal movements can be much more accurate when the degree of geographic variation in stable isotope values are known (Ostrom et al. 1993, Davenport and Bax 2002).

Another important factor to be taken into consideration is the turnover or incorporation rates from stable isotopes and the time-frame they represent, where tissues such as skin and muscle have a faster ra te when compared to tissues such as bones (Shoeninger and DeNiro 1984, Radtke et al. 1996, Busquets-Vass et al. 2017). This is relevant as different tissues have been used for the analysis of stable isotopes in baleen whales, such as skin, muscle, bone, brain, and liver (e.g. Borrel et al. 2012, Roubira et al. 2015). Besides, the small but progressive increase in animal tissue $\delta^{13} \mathrm{C}$ values with increasing trophic level can be observed from the base of the food web to higher consumers in pelagic communities (Rau et al. 1983).

Concepts and terminologies (e.g. isotopic fractionation and discrimination) in SIA have been reviewed by Newsome et al. (2010), as well as its general applications in ecological studies of marine mammals. Different reviews have also addressed the use of SIA in studies about animal movement and migrations (Hobson 1999, Graham et al. 2010, McMahon et al.2013a, McMahon et al.2013b), trophic ecology (Boecklen et al. 2011, Ramos and GonzálezSolís 2012), diet and metabolism (Ostrom and Fry 1993), relationship of contaminant concentrations in an organism to its dietary characteristics (Jardine et al. 2006), and general use of this methodology on marine mammals from the Southwestern Atlantic Ocean (Seyboth et al. 2017).

Considering the importance of this group and that no review of this kind has focused on baleen whales, we provide a compilation of the works related to this subject that were published up to 2017. The main objective of this work was to review which species were studied the most with this method, most frequent tissues analyzed, and how SIA has been applied in different ecological studies involving baleen whale species in different sites worldwide. We report on relevant information obtained by the application of this method, pertinent for management and conservation of this group.

\section{MATERIAL AND METHODS}

We summarize findings of peer reviewed papers applying SIA to the study of different aspects of the ecology and biology of baleen whales published between November 1979 and June 2017 (Table 1). To find peer reviewed papers we used search engines looking for key terms such as "stable isotopes" plus the species names. We also reviewed any reference cited in the papers that concerned the application of the methodology within the taxon. Papers published prior to January-2009 and reviewed by Newsome et al. (2010) were also included. The classification of the publications' main topics was kept in accordance to the aforementioned review, as: physiology and fractionation, foraging ecology and habitat use, population structure, and historic ecology and paleoecology. The number of publications using SIA in baleen whales, the frequency of studies on different species, and the type of tissues sampled have also been assessed. Moreover, we highlight insights acquired with the method about of whales' ecology considering their potential for conservation practices.

\section{RESULTS}

There was a substantial increase in the number of papers using SIA to study the ecology of baleen whales (Figure 1), 32 of which have been published since the review by Newsome et al. (2010) totalizing 63 publications in the $1980-2017$ period. Although the first study using SIA in baleen whales was published in 1980 (Killingley 1980), 49\% (31) of the studies have been published in the last seven and a half years, between 2011 and 2017.

From the total 14 species of baleen whales currently recognized by the Committee on Taxonomy (2014), 11 have been investigated somehow with the use of SIA (Figure 2). These species were not equally investigated considering the number of published researches with the method. To the best of our knowledge, there were no peer reviewed papers using SIA in Omura's whale, North Pacific Right whale (Eubalaena japonica), nor in Antarctic minke whale (Balaenoptera bonaerensis) in the period included in this review. On the other hand, there were at least 19 


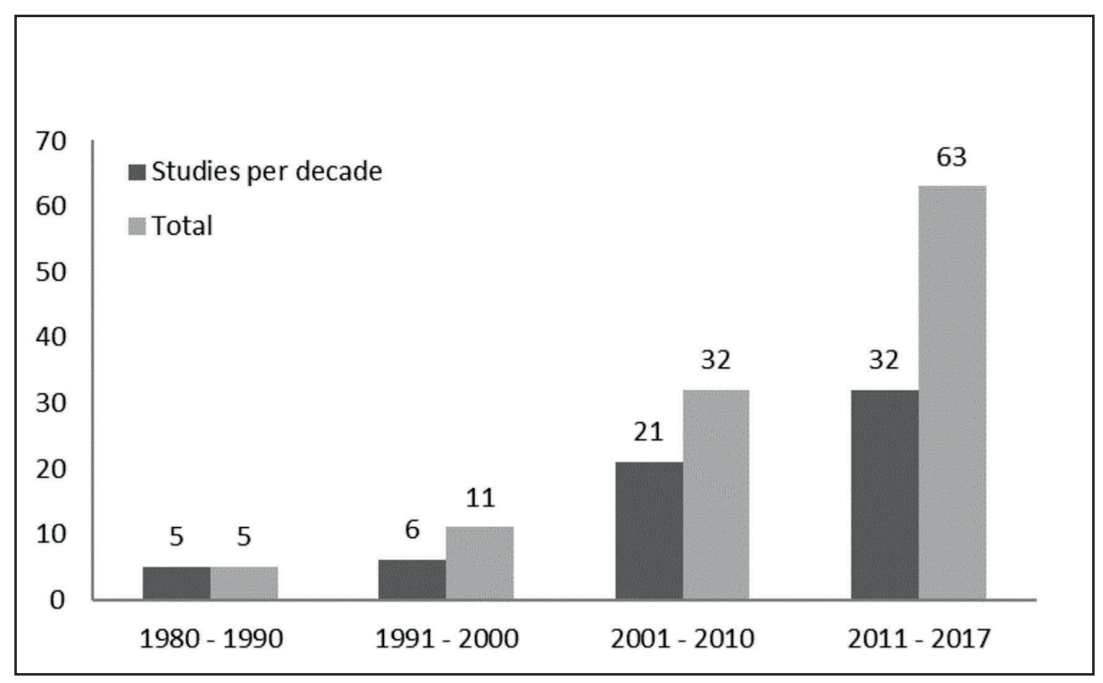

Figure 1. Number of studies on the ecology of baleen whales utilizing stable isotopes analysis per decade and cumulative numbers of studies. The dark-grey bars represent the number of new studies published during that period and the light-grey bars represent the cumulative number of publications along time.

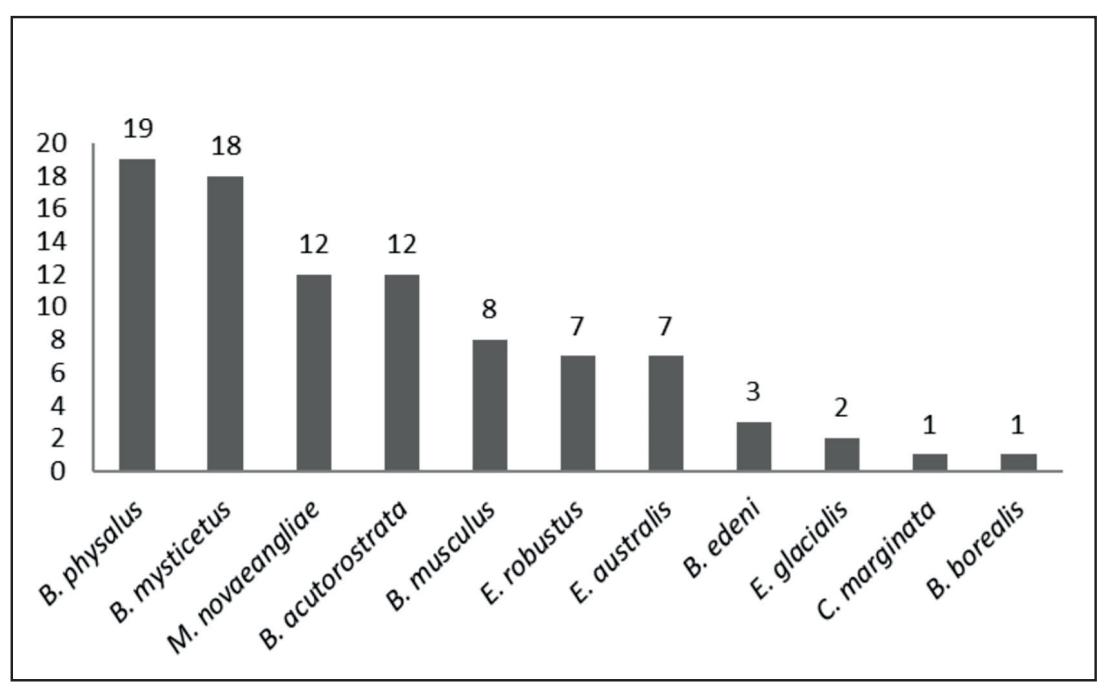

Figure 2. Total number of publications per species of baleen whales utilizing stable isotope analysis.

studies with this method in fin whales and 18 with bowhead whales.

The number of studies was significantly higher in the Northern Hemisphere $(n=54)$ in comparison to the Southern Hemisphere $(n=12)$ (Table 1), and only two studies included both hemispheres (Shoeninger and DeNiro, 1984, Clementz et al. 2014). All the SIA studies with fin whales were carried out in the Northern Hemisphere. The temporal and spatial variability on the feeding ecology and habitat use of whales are the main themes of the studies using SIA found in this review (Figure 3). The most frequently used tissue for SIA in this group were baleen plates $(n=26)$ (Figure 4). Those structures are generally collected from stranded animals as well as museum specimens. Skin was also frequently used $(n=24)$ as it can be collected through biopsies of live individuals or from stranded specimens, depending on the decomposition stage of the carcass. The number of studies using a combination of tissues amongst the different genera is significantly smaller when compared to those using a single type of tissue (Figure 4). 
Table 1. List of publications organized by species, including local of sampling, and tissue analyzed. Codes for main topic covered: 1 (Foraging ecology/ Habitat Use); 2 (Physiology/fractionation); 3 (Population structure); and 4 (Historic ecology). Codes for tissues sampled: B (Blubber); BA (Barnacles); BO (Bones); BP (Baleen plates); BR (Brain); F (Faeces); K (Kidney); L (Liver); M (Muscle); S (Skin); and V (Visceral fat). Code for elements: N (Nitrogen); C (Carbon), O (Oxygen), PB (Lead), and S (Sulphur). Code for Hemispheres: S (Southern), N (Northern). Only peer reviewed articles that were published prior to June-2017 are present except for Milmann et al. 2018 which was in press when this review was developed.

\begin{tabular}{|c|c|c|c|c|c|c|}
\hline Whale species & Local & Hemisphere & Tissues & Authors & $\begin{array}{l}\text { Main } \\
\text { topic }\end{array}$ & Element \\
\hline Balaena mysticetus & Barrow- Alaksa & $\mathrm{N}$ & B & Budge et al. 2008 & 1 & $\mathrm{C}$ \\
\hline Balaena mysticetus & Alaska & $\mathrm{N}$ & $\mathrm{BP}, \mathrm{M}, \mathrm{V}$ & Schell et al. $1989^{\mathrm{a}}$ & 1,2 & $\mathrm{C}$ \\
\hline Balaena mysticetus & Alaska & $\mathrm{N}$ & $\mathrm{BP}, \mathrm{M}$ & Schell et al. $1989^{\mathrm{b}}$ & 1,2 & $\mathrm{C}, \mathrm{N}$ \\
\hline Balaena mysticetus & Eastern Arctic & $\mathrm{N}$ & $\mathrm{BP}$ & $\begin{array}{c}\text { Hobson and Schell, } \\
1998\end{array}$ & 1 & $\mathrm{C}, \mathrm{N}$ \\
\hline Balaena mysticetus & Arctic & $\mathrm{N}$ & $\mathrm{BP}, \mathrm{M}$ & Lee et al. 2005 & 1 & $\mathrm{C}, \mathrm{N}$ \\
\hline Balaena mysticetus & Arctic & $\mathrm{N}$ & M & Hoekstra et al. 2002 & 1 & $\mathrm{C}, \mathrm{N}, \mathrm{S}$ \\
\hline Balaena mysticetus & Bering sea (Arctic) & $\mathrm{N}$ & $\mathrm{BP}$ & Schell, 2001a & 4 & $\mathrm{~N}$ \\
\hline Balaena mysticetus & Arctic & $\mathrm{N}$ & M & Hobson et al. 2002 & 1.2 & $\mathrm{C}, \mathrm{N}$ \\
\hline Balaena mysticetus & Bering Sea & $\mathrm{N}$ & $\mathrm{BP}$ & Schell, 2001b & 4 & $\mathrm{C}$ \\
\hline Balaena mysticetus & $\begin{array}{c}\text { Eastern Canada-West } \\
\text { Greenland }\end{array}$ & $\mathrm{N}$ & $\mathrm{BP}$ & $\begin{array}{l}\text { Matthews and } \\
\text { Ferguson, } 2015\end{array}$ & 1,2 & $\mathrm{C}, \mathrm{N}, \mathrm{S}$ \\
\hline Balaena mysticetus & Canadian eastern Arctic & $\mathrm{N}$ & $\mathrm{S}$ & Pomerleau et al. 2012 & 1 & $\mathrm{C}, \mathrm{N}$ \\
\hline Balaena mysticetus & West Greenland Ocean & $\mathrm{N}$ & $\mathrm{S}$ & Pomerleau et al. 2017 & 1 & $\mathrm{C}, \mathrm{N}$ \\
\hline Balaena mysticetus & Canadian eastern Arctic & $\mathrm{N}$ & B & Pomerleau et al. 2014 & 1.3 & $\mathrm{C}, \mathrm{N}$ \\
\hline $\begin{array}{l}\text { Balaena mysticetus, } \\
\text { Balaenoptera acutorostrata, } \\
\text { Balaenoptera borealis, } \\
\text { Balaenoptera edeni, } \\
\text { Balaenoptera musculus, } \\
\text { Balaenoptera physalus, } \\
\text { Caperea marginata, } \\
\text { Eschrichtius robustus, } \\
\text { Eubalaena australis, } \\
\text { Eubalaena glacialis, } \\
\text { Megaptera novaeangliae }\end{array}$ & USA, New Zealand & $\mathrm{N}$ & $\mathrm{BO}$ & Clementz et al. 2014 & 1,4 & $\mathrm{C}, \mathrm{O}$ \\
\hline $\begin{array}{l}\text { Balaena mysticetus, } \\
\text { Balaenoptera acutorostrata, } \\
\text { Balaenoptera musculus, } \\
\text { Balaaenoptera physalus, } \\
\text { Eschrichtius robustus }\end{array}$ & $\begin{array}{l}\text { Alaska, Southern and } \\
\text { Northern Pacific }\end{array}$ & $\mathrm{N}, \mathrm{S}$ & $\mathrm{BO}$ & $\begin{array}{l}\text { Shoeninger and } \\
\text { DeNiro, } 1984\end{array}$ & 1,2 & $\mathrm{C}, \mathrm{N}$ \\
\hline $\begin{array}{l}\text { Balaena mysticetus, } \\
\text { Balaenoptera acutorostrata, } \\
\text { Balaenoptera physalus, } \\
\text { Megaptera novaeangliae }\end{array}$ & $\begin{array}{c}\text { Gulf of St. Lowrence- } \\
\text { Canada }\end{array}$ & $\mathrm{N}, \mathrm{S}$ & $\mathrm{B}, \mathrm{M}, \mathrm{S}$ & Lesage et al. 2010 & 1,3 & $\mathrm{C}, \mathrm{N}$ \\
\hline $\begin{array}{l}\text { Balaena mysticetus, } \\
\text { Eschrichtius robustus }\end{array}$ & $\begin{array}{l}\text { Alaska, Russia and } \\
\text { California gulf }\end{array}$ & $\mathrm{N}$ & M, S & $\begin{array}{l}\text { Horstmann-Dehn et al. } \\
2012\end{array}$ & $1,2,4$ & $\mathrm{C}, \mathrm{N}$ \\
\hline $\begin{array}{l}\text { Balaena mysticetus, } \\
\text { Eschrichtius robustus }\end{array}$ & Alaska and Chucotka & $\mathrm{N}$ & M & Dehn et al. 2006 & 1 & $\mathrm{C}, \mathrm{N}$ \\
\hline Balaenoptera acutorostrata & $\begin{array}{c}\text { West Greenland, } \\
\text { Northeastern Atlantic } \\
\text { Ocean and the North Sea }\end{array}$ & $\mathrm{N}$ & BP, L, M & Born et al. 2003 & 3 & $\mathrm{C}, \mathrm{N}$ \\
\hline Balaenoptera acutorostrata & North Atlantic & $\mathrm{N}$ & $\begin{array}{l}\mathrm{BP}, \mathrm{L}, \\
\mathrm{M}, \mathrm{K}\end{array}$ & Hobson et al. 2004 & 2 & $\mathrm{C}, \mathrm{N}$ \\
\hline Balaenoptera acutorostrata & $\begin{array}{c}\text { Southwestern Atlantic } \\
\text { Ocean }\end{array}$ & $\mathrm{S}$ & $\mathrm{L}, \mathrm{K}$ & Milmann et al. 2018 & 1,2 & $\mathrm{C}, \mathrm{N}$ \\
\hline
\end{tabular}




\begin{tabular}{|c|c|c|c|c|c|c|}
\hline Whale species & Local & Hemisphere & Tissues & Authors & $\begin{array}{l}\text { Main } \\
\text { topic }\end{array}$ & Element \\
\hline Balaenoptera acutorostrata & Australia & $\mathrm{S}$ & M & $\begin{array}{l}\text { Davenport and Bax, } \\
2002\end{array}$ & 1 & $\mathrm{C}, \mathrm{N}$ \\
\hline Balaenoptera acutorostrata & Northwestern Pacific & $\mathrm{N}$ & $\mathrm{BP}$ & Mitani et al. 2006 & 1 & $\mathrm{C}, \mathrm{N}$ \\
\hline $\begin{array}{l}\text { Balaenoptera acutorostrata, } \\
\text { Balaenoptera musculus, } \\
\text { Balaenoptera physalus, } \\
\text { Megaptera novaeangliae }\end{array}$ & $\begin{array}{c}\text { Gulf of St. Lawrence- } \\
\text { Canada }\end{array}$ & $\mathrm{N}$ & $\mathrm{S}$ & Gavrilchuk et al. 2014 & 1 & $\mathrm{C}, \mathrm{N}$ \\
\hline $\begin{array}{l}\text { Balaenoptera acutorostrata, } \\
\text { Balaenoptera musculus, } \\
\text { Megaptera novaeangliae }\end{array}$ & $\begin{array}{l}\text { Northwestern Atlantic } \\
\text { (Canada) }\end{array}$ & $\mathrm{N}$ & M & Ostrom et al. 1993 & 1 & $\mathrm{C}, \mathrm{N}$ \\
\hline $\begin{array}{l}\text { Balaenoptera acutorostrata, } \\
\text { Balaenoptera physalus, } \\
\text { Megaptera novaeangliae }\end{array}$ & Northeast Atlantic & $\mathrm{N}$ & BP & Ryan et al. 2013 & 1,3 & $\mathrm{C}, \mathrm{N}$ \\
\hline $\begin{array}{l}\text { Balaenoptera acutorostrata, } \\
\text { Balaenoptera physalus, } \\
\text { Megaptera novaeangliae }\end{array}$ & $\begin{array}{l}\text { Ireland and Boa Vista, } \\
\text { Cape Verde }\end{array}$ & $\mathrm{N}$ & $\mathrm{B}, \mathrm{S}$ & Ryan et al. 2012 & 2 & $\mathrm{C}, \mathrm{N}$ \\
\hline Balaenoptera edeni & $\begin{array}{l}\text { Gulf of California- } \\
\text { Mexico }\end{array}$ & $\mathrm{N}$ & $\mathrm{BP}$ & Niño-Torres et al. 2013 & 1 & $\mathrm{C}, \mathrm{N}$ \\
\hline $\begin{array}{l}\text { Balaenoptera edeni, } \\
\text { Balaenoptera musculus, } \\
\text { Balaenoptera physalus }\end{array}$ & $\begin{array}{l}\text { Gulf of California- } \\
\text { Mexico }\end{array}$ & $\mathrm{N}$ & $\mathrm{F}, \mathrm{S}$ & Gendron et al. 2001 & 1 & $\mathrm{C}, \mathrm{N}$ \\
\hline Balaenoptera musculus & $\begin{array}{c}\text { South Californa bight } \\
\text { and eastern tropical } \\
\text { Pacific }\end{array}$ & $\mathrm{N}$ & M & Rau et al. 1983 & 1 & $\mathrm{C}$ \\
\hline Balaenoptera musculus & $\begin{array}{c}\text { Gulf of California and } \\
\text { Costa Rica }\end{array}$ & $\mathrm{N}$ & BP, S & $\begin{array}{l}\text { Busquets-Vass et al. } \\
\qquad 2017\end{array}$ & 1,2 & $\mathrm{C}, \mathrm{N}, \mathrm{O}$ \\
\hline Balaenoptera physalus & $\begin{array}{l}\text { Eastern North Atlantic } \\
\text { and Mediterranean Sea }\end{array}$ & $\mathrm{N}$ & $\mathrm{BP}$ & Giménez et al. 2013 & 3 & $\mathrm{C}, \mathrm{N}$ \\
\hline Balaenoptera physalus & Mediterranean Sea & $\mathrm{N}$ & $\mathrm{BP}$ & Roubira et al. 2015 & 1,3 & PB \\
\hline Balaenoptera physalus & Spain & $\mathrm{N}$ & $\begin{array}{l}\mathrm{BP}, \mathrm{BO}, \\
\mathrm{BR}, \mathrm{K}, \mathrm{L} \\
\quad \mathrm{M}, \mathrm{S}\end{array}$ & Borrel et al. 2012 & 1,2 & $\mathrm{C}, \mathrm{N}$ \\
\hline Balaenoptera physalus & Spain & $\mathrm{N}$ & $\mathrm{BP}, \mathrm{M}$ & Aguilar et al. 2014 & 1,2 & $\mathrm{~N}$ \\
\hline Balaenoptera physalus & Mediterranean Sea & $\mathrm{N}$ & $\mathrm{BP}$ & Bentaleb et al. 2011 & 1 & $\mathrm{C}, \mathrm{N}$ \\
\hline Balaenoptera physalus & $\begin{array}{l}\text { West Iceland and } \\
\text { northwest Spain }\end{array}$ & $\mathrm{N}$ & $\mathrm{BO}$ & Vighi et al 2016 & 1,3 & $\mathrm{C}, \mathrm{N}, \mathrm{O}$ \\
\hline Balaenoptera physalus & $\begin{array}{l}\text { Celtic sea, } \\
\text { Mediterranean Sea, } \\
\text { North Atlantic }\end{array}$ & $\mathrm{N}$ & $\mathrm{B}, \mathrm{S}$ & Das et al. 2017 & 1,3 & $\mathrm{C}, \mathrm{N}$ \\
\hline Balaenoptera physalus & $\begin{array}{c}\text { Belgia, French, Dutch } \\
\text { North Sea }\end{array}$ & $\mathrm{N}$ & $\mathrm{K}, \mathrm{L}$ & $\begin{array}{c}\text { Van de Vijver et al. } \\
2003\end{array}$ & 2 & $\mathrm{C}, \mathrm{N}$ \\
\hline Balaenoptera physalus & Southern North Sea & $\mathrm{N}$ & M & Das et al. 2003 & 1 & $\mathrm{C}, \mathrm{N}$ \\
\hline $\begin{array}{l}\text { Balaenoptera physalus, } \\
\text { Megaptera novaeangliae }\end{array}$ & $\begin{array}{c}\text { Canada. Western North } \\
\text { Atlantic }\end{array}$ & $\mathrm{N}$ & $\mathrm{B}$ & Borobia et al. 1995 & 1 & $\mathrm{C}$ \\
\hline $\begin{array}{l}\text { Balaenoptera physalus, } \\
\text { Megaptera novaeangliae }\end{array}$ & Alaska, North Pacific & $\mathrm{N}$ & $\mathrm{S}$ & Witteveen et al. 2016 & 1 & $\mathrm{C}, \mathrm{N}$ \\
\hline $\begin{array}{l}\text { Balaenoptera physalus, } \\
\text { Megaptera novaeangliae }\end{array}$ & $\begin{array}{c}\text { Celtic Sea, North } \\
\text { Atlantic }\end{array}$ & $\mathrm{N}$ & $\mathrm{S}$ & Ryan et al. 2014 & 1 & $\mathrm{C}, \mathrm{N}$ \\
\hline Eschrichtius robustus & Mexico, EUA & $\mathrm{N}$ & BA & Killingley, 1980 & 1 & $\mathrm{O}$ \\
\hline Eschrichtius robustus & Mexico, Alaska & $\mathrm{N}$ & BP, S & $\begin{array}{l}\text { Caraveo-Patiño and } \\
\text { Soto, } 2005\end{array}$ & 1 & $\mathrm{C}$ \\
\hline Eschrichtius robustus & $\begin{array}{c}\text { Baja California Sur- } \\
\text { Mexico }\end{array}$ & $\mathrm{N}$ & $\mathrm{BP}$ & $\begin{array}{l}\text { Caraveo-Patiño et al. } \\
2007\end{array}$ & 1 & $\mathrm{C}, \mathrm{N}$ \\
\hline
\end{tabular}




\begin{tabular}{|c|c|c|c|c|c|c|}
\hline Whale species & Local & Hemisphere & Tissues & Authors & $\begin{array}{l}\text { Main } \\
\text { topic }\end{array}$ & Element \\
\hline Eubalaena australis & South Africa & S & $\mathrm{BP}$ & Best and Schell, 1996 & 1 & $\mathrm{C}, \mathrm{N}$ \\
\hline Eubalaena australis & $\begin{array}{c}\text { Southern Brazil and } \\
\text { Argentina }\end{array}$ & $\mathrm{S}$ & $\mathrm{BO}$ & Vighi et al. 2014 & 3 & $\mathrm{C}, \mathrm{N}, \mathrm{O}$ \\
\hline Eubalaena australis & $\begin{array}{l}\text { Península Valdez- } \\
\text { Argentina }\end{array}$ & $\mathrm{S}$ & $\mathrm{S}$ & Valenzuela et al. 2009 & 1,3 & $\mathrm{C}, \mathrm{N}$ \\
\hline Eubalaena australis & $\begin{array}{c}\text { Península Valdez- } \\
\text { Argentina }\end{array}$ & $\mathrm{S}$ & $\mathrm{BP}$ & Rowntree et al. 2007 & 1,3 & $\mathrm{C}$ \\
\hline Eubalaena australis & $\begin{array}{c}\text { Península Valdez- } \\
\text { Argentina }\end{array}$ & $\mathrm{S}$ & $\mathrm{BP}$ & Rowntree et al. 2001 & 1 & $\mathrm{C}, \mathrm{N}$ \\
\hline Eubalaena australis & New Zealand & $\mathrm{S}$ & $\mathrm{B}, \mathrm{S}$ & Torres et al. 2016 & 1 & $\mathrm{C}, \mathrm{N}$ \\
\hline Eubalaena glacialis & North Atlantic & $\mathrm{N}$ & $\mathrm{BP}$ & Hunt et al. 2016 & 2 & $\mathrm{C}, \mathrm{N}$ \\
\hline Megaptera novaeangliae & Northwest Atlantic & $\mathrm{N}$ & $\mathrm{B}, \mathrm{M}, \mathrm{S}$ & Todd, 1997 & 2 & $\mathrm{C}$ \\
\hline Megaptera novaeangliae & Califonia - EUA & $\mathrm{N}$ & $\mathrm{B}$ & Clark et al. 2016 & 2 & $\mathrm{C}, \mathrm{N}$ \\
\hline Megaptera novaeangliae & Australia & $\mathrm{S}$ & $\mathrm{BP}$ & Eisenmann et al. 2016 & 1 & $\mathrm{C}, \mathrm{N}$ \\
\hline Megaptera novaeangliae & USA & $\mathrm{N}$ & $\mathrm{S}$ & Fleming et al. 2016 & 1 & $\mathrm{C}, \mathrm{N}$ \\
\hline Megaptera novaeangliae & $\begin{array}{c}\text { North Pacific, Gulf of } \\
\text { Alaska }\end{array}$ & $\mathrm{N}$ & $\mathrm{S}$ & Wright et al. 2015 & 1,3 & $\mathrm{C}, \mathrm{N}$ \\
\hline Megaptera novaeangliae & Alaska & $\mathrm{N}$ & $\mathrm{S}$ & Witteveen et al. 2012 & 1 & $\mathrm{C}, \mathrm{N}$ \\
\hline Megaptera novaeangliae & $\begin{array}{c}\text { North Pacific, Alaska, } \\
\text { Canada, EUA }\end{array}$ & $\mathrm{N}$ & S & Witteveen et al. 2009a & 1 & $\mathrm{C}, \mathrm{N}$ \\
\hline Megaptera novaeangliae & North Pacific & $\mathrm{N}$ & $\mathrm{B}, \mathrm{S}$ & Witteveen et al. 2009b & 1 & $\mathrm{C}, \mathrm{N}$ \\
\hline Megaptera novaeangliae & North Pacific & $\mathrm{N}$ & $\mathrm{B}, \mathrm{S}$ & Witteveen et al. 2011 & 1 & $\mathrm{~N}$ \\
\hline Megaptera novaeangliae & Antarctica, Australia & $\mathrm{S}$ & BP. S & Eisenmann et al. 2017 & 1 & $\mathrm{C}, \mathrm{N}$ \\
\hline Megaptera novaeangliae & $\begin{array}{c}\text { North Pacific, Berring } \\
\text { Sea }\end{array}$ & $\mathrm{N}$ & $\mathrm{B}, \mathrm{S}$ & Filatova et al. 2013 & 1 & $\mathrm{C}, \mathrm{N}$ \\
\hline
\end{tabular}

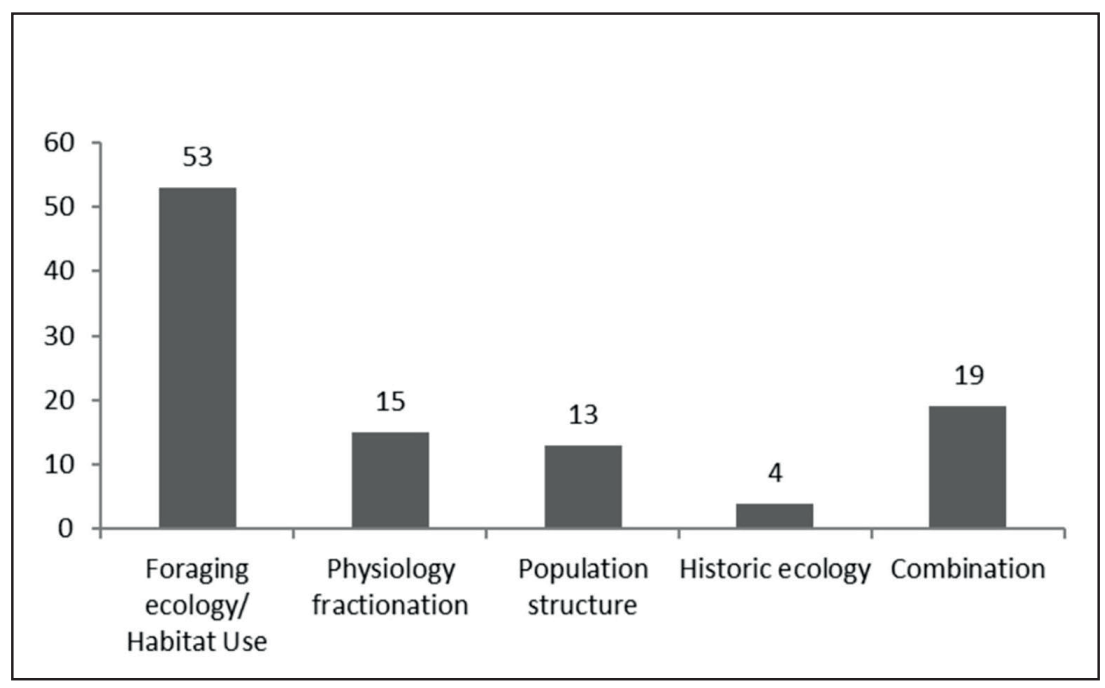

Figure 3. Number of studies on different topics using stable isotopes analysis. Some studies were listed in more than one column, as they can include more than one topic. 


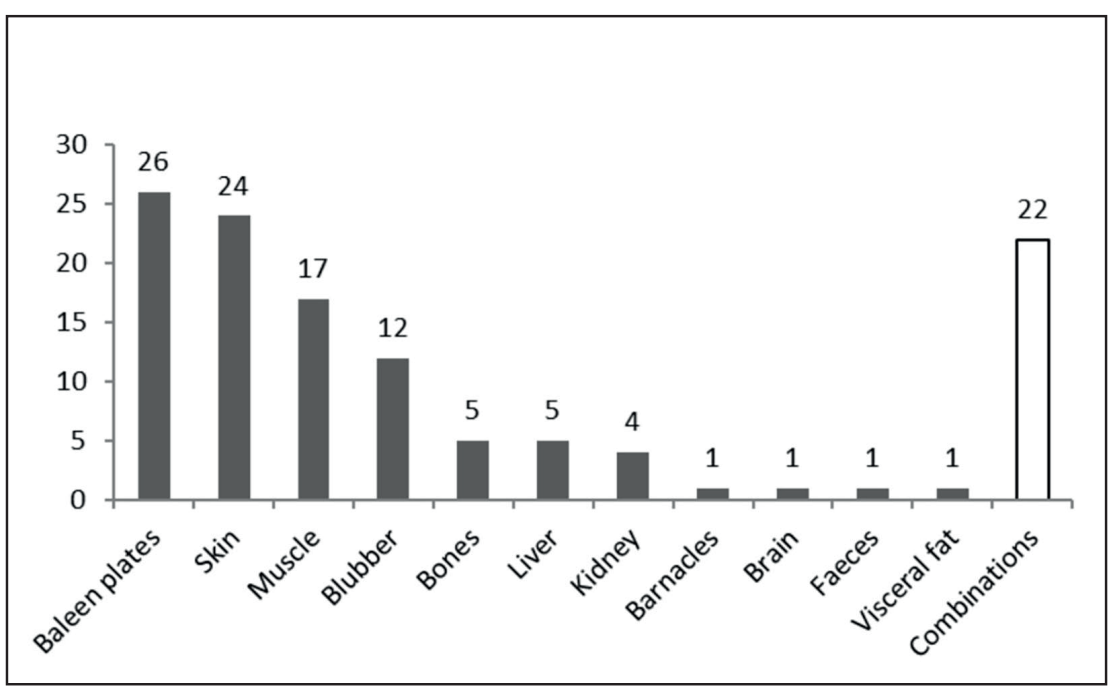

Figure 4. Total number of different tissues sampled for stable isotope analysis in the reviewed studies of baleen whales. When a study used different tissues, it is shown in the individual tissue column as well as in combination of different tissues in the same publication.

\section{DISCUSSION}

Considering the publication covered by this review, it is possible to detect that most baleen whale species have been investigated using SIA, evidencing the significance and applicability of this tool for the study of this group of animals. One of the reasons for the increasing use of SIA, particularly for different whale species, is its usefulness when compared with more traditional methodologies such as stomach content analysis or technological methodologies such as telemetry (Boyd et al. 2010, McMahon et al. 2013b). For example, depending on the turnover rate of the tissue analyzed, SIA can document greater time spans than conventional diet studies based on the identification of undigested prey remains such as otoliths and cephalopod beaks (Bowen 2000, Santos and Haimovici 2001). Furthermore, the analysis of multiple tissues allows the inferences of dietary information over different time frames, although stomach content analysis may provide more accurate information regarding prey species identification (Boyd et al. 2010). Besides, the relatively low cost of SIA when compared to telemetry studies is also an advantage, even though the latter technique can reveal the whale exact position along time (e.g. Horton et al. 2020). This approach can also provide valuable information on the trophic ecology of rare or evasive species, which may be difficult to observe and sample during the entire year, and data collection depends on a limited encounter opportunity. In this context, many migratory baleen whales may be unavailable to researchers for significant periods of their life cycles other than during breeding seasons when they can be found in mid-low latitudes andlor close to shore. Moreover, SIA is particularly helpful to elucidate ocean ecology issues and to track top predators (Ramos and González-Solís 2012) because most animals in an area can be labeled without having to be tagged or captured, even though biopsies must be collected. On the other hand, SIA has some limitations, as the isotopic values at the base of the food webs where the whales are feeding (isoscapes) need to be known in order to relate them with the patterns in whale stable isotopes. In addition, the tissue growth rate and turnover time are needed to interpret the data and make ecological inferences.

The larger number of studies in the Northern Hemisphere in comparison to the Southern Hemisphere is in part linked to the fact that both gray whale (Eschricthius robustus) and bowhead whale (the second species in number of publications, Figure 2) are restricted to this area (Rugh et al. 2008). In any case, even excluding all studies from both species, the number of studies in the Northern Hemisphere is still greater. Moreover, a recent review on the application of SIA to the study of marine mammals in the Southwestern Atlantic Ocean (Seyboth et al. 2017) pointed out that the only baleen whale species studied with the use of SIA in Brazil and Argentina was the Southern right whale (Rowntree et al. 2007, Valenzuela et al. 2009, Vighi et al. 2014). Information regarding whales is relatively scarce in that area (Rocha-Campos and Câmara 2011, 
Crespo 2012, Milmann et al. 2020), and the lack of SIA studies in the Southwestern Atlantic Ocean despite the potential to elucidate aspects related to movements (Giménez et al. 2013, Busquets-Vass et al. 2017), for example, reinforce that the use of stable isotopes should be encouraged in the area as in the Southern Hemisphere in general.

The majority of the studies applied stable isotopes to assess the foraging ecology and habitat use (Figure 3), similar to the trends reported for marine mammals in general by Newsome et al. (2010). Despite the relatively lower frequency of studies on physiology and fractionation on stable isotope ratios, such studies are of great importance to understand and apply SIA with greater accuracy. Studies have made empirical tests using samples from wild animals (e.g. Lesage et al. 2010, BusquetsVass et al. 2017) evidencing that $\delta^{15} \mathrm{~N}$ values do not reflect fasting in baleen whales (Aguilar et al. 2014). Nevertheless, a recent study revealed that $\delta^{15} \mathrm{~N}$ values are higher during fasting in pinnipeds (Lübcker $e t$ al. 2020). These studies are useful to understand metabolic factors such as incorporation, fractionation, and routing processes of tracers in different tissues. The use of SIA for historic ecology allows a better understanding of how movement patterns for living species have changed over time (Clementz et al. 2014). Also, analysis of $\delta^{13} \mathrm{C}$ and $\delta^{18} \mathrm{O}$ values from ancient individuals of toothed cetaceans and baleen whales corroborated the speciation time for this group and probable irradiation of cetaceans during the Oligocene (Clementz et al. 2014). Yet, this type of study requires well preserved hard structures of ancient whales for analysis. Thus, studies on ecology of ancient whales are scarcer than those evaluating feeding ecology and movement, physiology and fractionation as well as stock structure of extant whales (Figure 3).

Controlled experiments to test stable isotope turnover rate in whale tissues are practically impossible to perform as this would ideally require keeping individuals in captivity. However, comparing values from prey, skin and baleen plates of blue whales, the skin incorporation of $\delta^{15} \mathrm{~N}$ was estimated to be $163 \pm 91$ days (Busquets-Vass et al. 2017). Blood tissues have relatively fast incorporation rate, followed by muscle, while tissues such as bones have slow turnover rates and dietary information can be incorporated over several years (Radtke et al. 1996). Therefore, the analysis of tissues that can record at least two migration cycles combined with those reflecting short-term diet composition, such as skin and muscle, provide different time scale responses. Together they are effective to elucidate animal movements and population structure (Vighi et al. 2016), as well as physiological aspects such as the effect of fasting in stable isotope values of whales (Busquets-Vass et al. 2017).

There are sources of individual variation in the incorporation rates related to different tissues, nutritional state, specific metabolic rates, ontogenetic states, body size, and growth rate (e.g. Lee et al. 2005, Mitani et al. 2006, Crawford et al. 2008, Newsome et al. 2010, Busquets-Vass et al. 2017). For humpback whales (Megaptera novaeangliae), effects of pregnancy on $\delta^{15} \mathrm{~N}$ and $\delta^{13} \mathrm{C}$ values through increased mobilization of lipid stores to meet the energetic demands were reported, which are probably related to tissue synthesis and reduction in excretion of nitrogenous waste (Clark et al. 2016). Some studies focused on the effect of sample preservation, lipid extraction, and lipid normalization in baleen whales' stable isotopes (e.g. Shoeninger and DeNiro 1984, Hobson et al. 2002, Lesage et al. 2010). For example, higher $\delta^{15} \mathrm{~N}$ values were observed in the common minke whale and fin whale after lipid extraction of skin and blubber samples (Ryan et al. 2012). For the fin whale, lipid-extracted samples had higher $\delta^{13} \mathrm{C}$ values over untreated samples by an average of $2.9 \%$, while there was a slight increase of $0.14 \%$ in $\delta^{15} \mathrm{~N}$ values (Das et al. 2017).

The isotopic composition amongst the three different skin strata (stratum externum, stratum spinosum, and stratum basale) has been described for the blue whale (Busquets-Vass et al. 2017) and for different tissues of the fin whale (Borrel et al. 2012). Although stable isotope values in gray whale epidermis were significantly enriched in ${ }^{15} \mathrm{~N}$ over muscle, while skin was more ${ }^{13} \mathrm{C}$-depleted than muscle, the epidermis samples were considered an adequate replacement for muscle tissue in comparative feeding ecology studies (HorstmannDehn et al. 2012). Although stable sulphur isotopes are not commonly used as they are not sensitive to variation in trophic level, it can be used in areas with anthropogenic or geological signatures (Hoekstra et al. 2002). Their values are also potentially useful for discerning between trophic and spatial influences that can lead to ambiguous interpretations of $\delta^{15} \mathrm{~N}$ and $\delta^{13} \mathrm{C}$ values and may reflect periods of restricted food consumption (Matthews and Ferguson 2015). Finally, there is a difference in $\delta^{15} \mathrm{~N}$ values between stranded and free-ranging whales, probably because body protein catabolism leads to ${ }^{15} \mathrm{~N}$ enrichment (Hobson et al 1993). In this context, SIA-based studies have been used to raise attention to differences in stable 
isotope values between dead and live whales, due to a possible nutritional stress of the former prior to its death (Horstmann-Dehn et al. 2012). This particularity should be considered for interpretation of results when tissues derived from carcasses are subject to SIA.

The interpretation of SIA results can be more clarifying when linked to different methodologies such as telemetry (Bentaleb et al. 2011), photoidentification (Witteveen et al. 2009a, Torres et al. 2016), stomach content and prey analysis (Caraveo-Patiño and Soto 2005, Fleming et al. 2016, Milmann et al. 2018), contaminants (Hobson et al. 2002), radiocarbon (Das et al. 2017), molecular (Rowntree et al. 2001, Torres et al. 2016), and fatty acids biomarkers (Borobia et al. 1995, Budge et al. 2008). These studies elucidate issues related to life cycle, contaminant properties, aspects of ecology, physiology, migratory movements, stock boundaries, foraging habits (resource partitioning) and food web structure.

The use of SIA in combination with molecular analysis can subside stocks identification. With the use of such methodologies, it was confirmed that individuals sharing haplotypes have closer isotopic values than expected when comparing with other haplotypes, indicating that southern right whales from the same matrilineal line tend to consume more similar resources when compared with less related individuals (Valenzuela et al. 2009). The conjunction between SIA and telemetry provides an opportunity for scientists to calibrate and expand their tools in marine ecology, specifically through the development and eventual utilization of $\delta^{13} \mathrm{C}$ and $\delta 15 \mathrm{~N}$ marine isoscapes (Graham et al. 2010).

Many studies using SIA provide data that can be applied for conservation practices (e.g. Valenzuela et al. 2009, Pomerleau et al. 2012, Fleming et al. 2016). Population and stock structure studies, which are fundamental for conservation and management (Boyd et al. 2010), have elucidated important particularities amongst different stocks of the same species. For example, several characteristics of the spatial distribution of the Mediterranean fin whale were assessed using lead $(\mathrm{Pb})$ stable isotopes, revealing the degree of connection among the Atlantic Ocean and Mediterranean Sea populations (Giménez et al. 2013, Roubira et al. 2015). For the same species, stable isotopes revealed that although they occupy the North Sea seasonally, they probably feed elsewhere (Das et al. 2003). Also, a narrower isotopic niche width of the Mediterranean population of fin whales in relation to the North
Atlantic population raises concerns in the context of global changes and long-term consequences for the Mediterranean fin whales (Das et al. 2017).

The use of SIA has also revealed that in the Gulf of California humpback whales have feeding plasticity that can reflect climate changes and consequent fluctuations in prey abundance (Fleming et al. 2016). The capacity to respond to such events is an important ecological aspect of this species and has value for conservation. The fact that, although there is some trophic overlap, a diet segregation amongst sympatric and closely-related Balaenoptera species exists (e.g. Ostrom et al. 1993, Borobia et al. 1995, Gavrilchuk et al. 2014) evidences an important aspect of the role of these species in the environment and food webs. In addition, from the ecosystem perspective, depletion trends in $\delta^{13} \mathrm{C}$ values of fin whale baleen plates revealed an increase in the input of nutrients and of anthropogenic carbon in the Western Mediterranean Sea (Bentaleb et al. 2011), highlighting the importance of the methodology for the evaluation and conservation of ecosystems.

\section{CONCLUSIONS}

Stable isotope analysis has been widely used to study baleen whale trophic ecology and habitat use, as it allows the investigation of diet and movement records of periods when the animal could not be directly observed and skin sampling is relatively non-invasive. Our analysis showed that the species most frequently studied using SIA in the investigated period were the fin whale and the bowhead whale, although almost all baleen whale species have been studied somehow using the methodology. The continuation of the use of SIA to improve the understanding of different aspects of the ecology of baleen whales will be benefic for their conservation, especially if used in combination with other methods, such as telemetry and photo-id. The baleen plates are structures unique to this group and provide an important source of information that allow longterm record of stable isotopes. Therefore, they are the most frequently analyzed tissue from baleen whales. However, studies using bones from scientific collections are still poorly represented and are a noninvasive alternative to gather several information on ecological aspects of Balaenopteridae. Despite the relatively short-term dietary information obtained through the analysis of skin, it has been widely used for the group, as it can be more easily collected through biopsy samples. Studies on physiology and fractionation are relatively scarcer when compared 
to those aiming to clarify feeding ecology and habitat use issues, which is expected, as animals cannot be kept in captivity or easily be sampled along different seasons. Although investigations can be developed using a combination of tissues, the number of studies analyzing a single tissue is significantly higher than those with multiple tissue types. Some aspects need to be considered for a better interpretation of SIA such as different turnover periods between tissues and sample treatment, but the results revealed a significant amount of data regarding ecological and evolutionary aspects of baleen whales. Moreover, they have great potential to provide information for conservation of less known species, especially where information about the ecosystem is desirable for management purposes, as is the case of the South Atlantic Ocean.

\section{ACKNOWLEDGEMENTS}

This research was financially supported by Cetacean Society International (CSI), Rufford, USA (Small Grant No 24023-1), and Fundação de Apoio a Pesquisa da Bahia (Fapesb), Brazil through a $\mathrm{PhD}$ scholarship to the first author. S. Siciliano is supported by CNPq (Produtividade em Pesquisa). We also would like to thank Alexandra Fernandes Costa, Elisa Seyboth and Genyffer C. Troina for peer reviewing this article.

\section{REFERENCES}

Aguilar, A., Giménez, J., Gómez-Campos, E., Cardona, L. \& Borrell, A. 2014. $\delta 15 \mathrm{~N}$ value does not reflect fasting in Mysticetes. PLoS ONE, 9(3): 1- 7.

Bentaleb, I., Martin, C., Vrac, M., Mate, B., Mayzaud, P., Siret, D., ... \& Guinet, C. 2011. Foraging ecology of Mediterranean fin whales in a changing environment elucidated by satellite tracking and baleen plate stable isotopes. Mar. Ecol. Prog. Ser., 438: 285-302.

Best, P.B. \& Schell, D.M. 1996. Stable Isotopes in southern right whale (Eubalaena australis) baleen as indicators of seasonal movements, feeding and growth. Mar. Biol., 124: 483-494.

Boecklen, W.J., Christopher, T.Y., Cook, B.A. \& James, A.C. 2011. On the use of stable isotopes in trophic ecology. Annual Review of Ecology, Evolution and Systematics, 42: 411-440.

Borrell, A., Abad-Oliva, N., Gomez-Campos, E.,
Giménez, J. \& Aguilar, A. 2012. Discrimination of stable isotopes in fin whale tissues and application to diet assessment in cetaceans. Rapid. Commun. Mass. Sp., 26: 1596-1602.

Born, E.W., Outrige, P., Riget, F.F., Hobsons, K.A., Dietz, R., Øie, N. \& Haug, T. 2003. Population substructure of North Atlantic minke whales (Balaenoptera acutorostrata) inferred from regional variation of elemental and stable isotopic signatures in tissues. J. Marine. Syst., 43: 1-17.

Borobia, M., Gearing, P.J., Simard, Y., Gearing, J.N. \& Béland, P. 1995. Blubber fatty acids of finback and humpback whales from the gulf of St. Lawrence. Mar. Biol., 122: 341-353.

Bowen, W.D. 2000. Reconstruction of pinniped diets: accounting for complete digestion of otoliths and cephalopod beaks. Can. J. Fish. Aquat. Sci., 57(5): 898-905.

Boyd, I.L., Bowen, W.D. \& Iverson, S.J. 2010. Marine Mammal Ecology and Conservation, A handbook of techniques. Oxford University Press, New York. 450 p.

Budge, S.M., Wooler, M.J., Springer, A.M., Iverson, S.J., McRoy, C.P. \& Divoky, G.J. 2008. Tracing carbon flow in an arctic marine food web using fatty acid-stable isotope analysis. Oecologia, 157: 117-129.

Busquets-Vass, G., Newsome, S.D., Calambokidis, J., Serra-Valente, G., Jacobsen, J.K., AguínigaGarcía, S. \& Gendron, D. 2017. Estimating blue whale skin isotopic incorporation rates and baleen growth rates: Implications for assessing diet and movement patterns in mysticetes. PLoS ONE, 12(5): $1-25$.

Caraveo-Patiño, J. \& Soto, L.A. 2005. Stable carbon isotope ratios of the gray whale (Eschrichtius robustus) in the breeding grounds of Baja California Sur, Mexico. Hydrobiologia, 539: 99-107.

Caraveo-Patiño, J., Hobson, K.A. \& Soto, L.A. 2007. Feeding ecology of gray whales inferred from stable-carbon and nitrogen isotopic analysis of baleen plates. Hydrobiologia, 586: 17-25.

Clapham, P.J., \& Baker, C.S. 2002. Modern whaling. In: Encyclopedia of marine mammals. (Eds. Perrin, W.F., Würsig, B., \& Thewissen, J.G.M.) Academic Press, New York, 1328-1332.

Clark, C.T., Fleming, A.H., Calambokidis, J., Kellar, N.M., Allen, C.D., Catelani, K.N., ... \& Harvey, J.T. 2016. Heavy with child? Pregnancy status and stable isotope ratios as determined from biopsies 
of humpback whales. Conservation Physiology, 4(1): 1-13.

Clementz, M.T., Fordyce, R.E., Peek, S.L. \& Fox, D.L. 2014. Ancient marine isoscapes and isotopic evidence of bulk-feeding by Oligocene cetaceans. Palaeogeography, Palaeoclimatology, Palaeoecology, 400: 28-40. Committee on Taxonomy. 2014. List of marine mammal species and subspecies. Society for Marine Mammalogy. www.marinemammalscience. org, consulted on November 4th, 2017.

Cooke, J.G. 2018. Balaenoptera borealis. The IUCN Red List of Threatened Species 2018: e.T2475A130482064. https://dx.doi.org/10.2305/ IUCN.UK.2018-2.RLTS.T2475A130482064.en. Downloaded on 11 August 2020.

Cooke, J.G. 2020. Eubalaena glacialis. The IUCN Red List of Threatened Species 2020: e.T41712A162001243. https://dx.doi.org/10.2305/ IUCN.UK.2020-2.RLTS.T41712A162001243.en. Downloaded on 11 August 2020.

Cooke, J.G. \& Brownell Jr., R.L. 2019. Balaenoptera omurai (amended version of 2018 assessment). The IUCN Red List of Threatened Species 2019: e.T136623A144790120. https://dx.doi.org/10.2305/ IUCN.UK.2019-1.RLTS.T136623A144790120.en. Downloaded on 11 August 2020.

Crawford, K., McDonald, R.A. \& Bearhop, S. 2008. Applications of stable isotope techniques to the ecology of mammals. Mammal Review, 38(1): 87-107.

Crespo, E.A. 2012. Orden Cetacea. In: Libro Rojo de Mamíferos Amenazados de la Argentina eds: R. A. Ojeda, Chillo, V. and G. B. D. Isenrath. pp. 129-133. Sociedad Argentina para el Estudio de los Mamíferos (SAREM), Argentina.

Fleming, A.H., Clark, C.T., Calambokidis, J. \& Barlow, J. 2016. Humpback whale diets respond to variance in ocean climate and ecosystem conditions in the California Current. Global Change. Biol., 22(3): 1214-1224.

Fry, B. 2006. Stable Isotope Ecology. Springer Science + Business Media. 308 p.

Gavrilchuk, K., Lesage, V., Ramp, C., Sears, R., Bérubé, M., Bearhop, S. \& Beauplet, G. 2014. Trophic niche partitioning among sympatric baleen whale species following the collapse of groundfish stocks in the Northwest Atlantic. Mar. Ecol. Prog. Ser., 497: 285-301.

Gendron, D., Aguíñiga, S. \& Carriquiry, J.D. 2001. $\delta 15 \mathrm{~N}$ and $\delta 13 \mathrm{C}$ in skin biopsy samples: a note on their applicability for examining the relative trophic level in three rorqual species. Journal of Cetacean Research Management, 3: 41-44.

Giménez, J., Gómez-Campos, E., Borrel, A., Cardona, L. \& Aguiar, A. 2013. Isotopic evidence of limited exchange between Mediterranean and eastern North Atlantic fin whales. Rapid Commun. Mass. Sp., 27: 1801-1806.

Graham, B.S., Koch, P.L., Newsome, S.D., McMahon, K.W. \& Aurioles, D. 2010. Using Isoscapes to Trace the Movements and Foraging Behavior of Top Predators in Oceanic Ecosystems. In: West JB et al. (Eds) Isoscapes: Understanding Movement, Pattern, and Process on Earth Through Isotope Mapping. Springer Science + Business Media B.V. 299-318.

Hobson, K., Alisauskas, R. \& Clark, R. 1993. Stable-Nitrogen Isotope Enrichment in Avian Tissues Due to Fasting and Nutritional Stress: Implications for Isotopic Analyses of Diet. The Condor, 95: 388394.

Hobson, K.A. 1999. Tracing origins and migration of wildlife using stable isotopes: a review. Oecologia, 120: 314-326.

Hobson, K.A., Fisk, A., Karnovsky, N., Holst, M., Gagnon, J. \& Fortier, M. 2002. A stable isotope $(\delta 13 \mathrm{C}, \delta 15 \mathrm{~N})$ model for the North Water food web: implications for evaluating trophodynamincs and the flow of energy and contaminants. Deep Sea Res, 49: 5131-5150.

Hobson, K.A., Riget, F.F., Outridge, P.M., Dietz, R. $\&$ Born, E. 2004. Baleen as biomonitor of mercury content and dietary history of North Atlantic Minke Whales (Balaenoptera acutorostrata) combining elemental and stable isotope approaches. Sci. Total Environ., 331: 69-82.

Hoekstra, P.F., Dehn, L.A., George, J.C., Solomon, K.R., Muir, D.C.G. \& O'hara, T.M. 2002. Trophic ecology of bowhead whales (Balaena mysticetus) compared with that of other arctic marine biota as interpreted from carbon-, nitrogen-, and sulfurisotope signatures. Can. J. Zool., 80: 223-231.

Horstmann-Dehn, L., Follmann, E.H., Rosa, C., Zelensky, G. \& George, C. 2012. Stable carbon and nitrogen isotope ratios in muscle and epidermis of arctic whales. Mar. Mammal Sci., 28(2): 173-190.

Horton, T.W., Zerbini, A.N., Andriolo, A., Danilewicz, D. \& Sucunza, F. 2020. Multi-Decadal Humpback Whale Migratory Route Fidelity Despite Oceanographic and Geomagnetic Change. Frontiers in Marine Science, 7:414. doi: 10.3389/ fmars.2020.00414 
Hunt, K.E., Lysiak, N.S., Moore, M.J. \& Rolland, R.M. 2016. Longitudinal progesterone profiles in baleen from female North Atlantic right whales (Eubalaena glacialis) match known calving history. Conservation Physiology, 4: 1-9.

Jardine, T.D., Kidd, K.A. \& Fisk, A.T. 2006. Applications, Considerations and Sources of Uncertainty When Using Stable Isotope Analysis in Ecotoxicology. Environ. Sci. Technol., 40: 75017511.

Killingley, J.S. 1980. Migrations of California Gray Whales Tracked by Oxygen-18 Variations in their epizoic Barnacles. Science, 207: 759-760.

Laist, D.W., Knowlton, A.R., Mead, J.G., Collet, A.S. \& Podesta, M. 2001. Collisions between ships and whales. Mar. Mammal Sci., 17: 35-75.

Learmonth, J.A., MacLeod, C.D., Santos, M.B., Pierce, G.J., Crick, H.Q.P. \& Robinson, R.A. 2006. Potential effects of climate change on marine mammals. Oceanography and Marine Biology, 44: 431-464.

Lee, S.H., Schell, D.M., McDonald, T.L. \& Richardson, W.J. 2005. Regional and seasonal feeding by bowhead whales Balaena mysticetus as indicated by stable isotope ratios. Mar. Ecol. Prog. Ser., 285: 271-287.

Lesage, V., Morin, Y., Rioux, E., Pomerleau, C., Ferguson, S.H. \& Pelletier, E. 2010. Stable isotopes and trace elements as indicators on diet and habitat use in cetaceans: predicting errors related to preservation, lipid extraction, and lipid normalization. Mar. Ecol. Prog. Ser., 419: 249-265.

Lübcker, N., Whiteman, J.P., Millar, R.P., Nico de Bruyn, P.J. \& Newsome, S.D. 2020. Fasting affects amino acid nitrogen isotope values: a new tool for identifying nitrogen balance of free-ranging mammals. Oecologia, 193: 53-65.

Magozzi, S., Yool, A., Vander Zanden, H.B., Wunder, M.B. \& Trueman, C.N. 2017. Using ocean models to predict spatial and temporal variation in marine carbon isotopes. Ecosphere, 8: e01763

Matthews, C.J.D. \& Ferguson, S.H. 2015. Seasonal foraging behavior of eastern Canada-West Greenland bowhead whales: An assessment of isotopic cycles along baleen. Mar. Ecol. Prog. Ser., 522: 269-286.

McMahon, K.W., Hamady, L.L. \& Thorrold, S.R. 2013a. Review of ecogeochemistry approaches to estimating movements of marine mammal. Limnol. Oceanograph. 58: 697-714.

McMahon, K.W., Hamady, L.L. \& Thorrold,
S.R. 2013b. Ocean Ecogeochemistry: a review. Oceanography and Marine Biology. edited by Hughes RN, Hughes DJ, Smith IP. In: Oceanography and marine biology an annual review 51:327-374.

Milmann, L., Machado, R., Sucunza, F., Oliveira, L.R., Santos, R.A., Di Beneditto, A.P.M., Rezende, C.E., Baumgarten, J. \& Ott, P.H. 2018. New trophic link and potential feeding area of dwarf minke whale (Balaenoptera acutorostrata subsp.) in mid latitude waters of the southwestern Atlantic Ocean. Mammalia, 83(1): 49-52.

Milmann, L., Siciliano, S., Morais, I., Tribulato, A.S., Machado, R., Zerbini, A.N., Baumgarten, J.E. \& Ott, P.H. 2020. A review of Balaenoptera strandings along the east coast of South America. Regional Studies in Marine Science, 37: 101343.

Mitani, Y., Bando, T., Takai, N. \& Sakamoto, W. 2006. Patterns of stable carbon and nitrogen isotopes in baleen of common minke whale Balaenoptera acutorostrata from the western North Pacific. Fisheries Science, 72: 69-75.

Morais, O.B.I., Danilewicz, D., Zerbini, A.M., Edmundson, W. \& Bortolotto, G.A. 2016. From the southern right whale hinting decline to the humpback whaling expansion: a reviw of whale catch records in the tropical western South Atlantic Ocean. Mamm. Rev., 13 p.

Newsome, S.D., Clementz, M.T. \& Koch, P.L. 2010. Using stable isotope biogeochemistry to study marine mammal ecology. Mar. Mammal. Sci., 26: 509-572.

Niño-Torres, A.C., Urbán, J. \& Olavarrieta, T. 2013. Dietary preferences of Bryde's whales (Balaenoptera edeni) from the gulf of California: A $\delta 13 \mathrm{C}, \delta 15 \mathrm{~N}$ analysis. Mar. Mammal. Sci., 30: 1140-1148.

Ostrom, P.H. \& Fry, B. 1993. Sources and Cycling of Organic Matter within Modern and Prehistoric Food Webs. In: Topics in Geobiology eds: $M$. H. Engel and S. A. Macko. Chapter 37:786-798. Springer Science-Business Media New York.

Ostrom, P.H., Lien, J. \& Macko, S.A. 1993. Evaluation of the diet of Sowerby's beaked whale, Mesoplodon bidens based on isotopic comparisons among northwestern Atlantic cetaceans. Can. J. Zool., 71: 858-861.

Pomerleau, C., Lesage, V., Ferguson, S.H., Winkler, G., Petersen, S.D. \& Higdon, J.W. 2012. Prey assemblage isotopic variability as a tool for assessing diet and the spatial distribution of bowhead whale Balaena mysticetus foraging in the Canadian eastern Arctic. Mar. Ecol. Prog. Ser. Series, 469: 161-174. 
Pomerleau, C., Lesage, V., Winkler, G., Rosenberg, B. \& Ferguson, S.H. 2014. Contemporary diet of bowhead whales (Balaena mysticetus) from the eastern Canadian arctic inferred from fatty acid biomarkers. Arctic, 67: 84-92.

Pomerleau, C., Heide-Jørgensen, M.P., Ferguson, S.H., Stern, H.L., Høyer, J.L. \& Stern, G.A. 2017. Reconstructing variability in West Greenland ocean biogeochemistry and bowhead whale (Balaena mysticetus) food web structure using amino acid isotope ratios. Polar. Biol., 40: 2225-2238.

Radtke, R.L., Showers, W., Moksness, E. \& Lenz P. 1996. Environmental information stored in otoliths: insights from stable isotopes. Mar. Biol., 127: 161170.

Ramos, R.A. \& González-Solís, J. 2012. Trace me if you can: the use of intrinsic biogeochemical markers in marine top predators. ., 10: 258-266.

Rau, G.H., Sweeney, R.E. \& Kaplant, I.R. 1982. Plankton 13C:12C ratio changes with latitude: differences between northern and southern oceans. Deep-Sea Research, 29: 1035-1039.

Rau, G.H., Mearns, A.J., Young, D.R., Olson, R.J., Schafer, H.A. \& Kaplan, I.R. 1983. Animal C13/C12 correlates with trophic level in pelagic food webs. Ecology, 64: 1314-1318.

Rocha-Campos, C.C. \& Câmara, I.G. 2011. Plano de ação Nacional Para Conservação dos Mamíferos Aquáticos: Grandes Cetáceos e Pinípedes. Instituto Chico Mendes de Conservação da Biodiversidade, Brasília.

Roubira, P., Bosch, D. \& Bentaleb, I. 2015. Pb isotopic compositions of fin whale baleen plates - A clue to unravel individual migrations between the Atlantic Ocean and the Mediterranean Sea? Procedia Earth and Planetary Science, 13: 173-176.

Rowntree, V., Payne, R. \& Schell, D. 2001. Changing patterns of habitat use by southern right whales (Eubalaena australis) on their nursery ground at Península Valdés, Argentina, and in their long-range movements. J. Cetacean Res. Manage. Special Issue, 2:133-143.

Rowntree, V.J., Valenzuela, L.O., Fraguas, P.F. \& Seger, J. 2007. Foraging behavior of southern right whales (Eubalaena australis) inferred from variation of carbon stable isotope ratios in their baleen. $\mathrm{J}$. Cetacean. Res. Manage., SC/60/BRG23. 10 p.

Rubestein, R. \& Hobson, K.A. 2004. From birds to butterflies: animal movement patterns and stable isotopes. Trends in Ecology \& Evolution, 19:
256-264

Rugh, D.J. \& Shelden, K.E.W. 2008. "Bowhead Whale". In Perrin WF., Würsig B, Thewissen JGM. Encyclopedia of Marine Mammals (Second ed.). Academic Press. p. 131.

Ryan, C., McHugh, B., Trueman, C.N., Harrod, C., Berrow, S.D. \& O'Connor, I. 2012. Accounting for the effects of lipids in stable isotope $(\delta 13 \mathrm{C}$ and $\delta 15 \mathrm{~N}$ values) analysis of skin and blubber of Balaenopteridae whales. Rapid Commun. Mass. Spectrom. 26: 2745-2754.

Ryan, C., McHugh, B., Trueman, C.N., Sabin, R., Deaville, R., Harrod, C., Berrow, S.D. \& O'Connor, I. 2013. Stable isotope analysis of baleen reveals resource portioning among sympatric rorquals and population structure in fin whales. Mar. Ecol. Prog. Ser., 479: 251-261.

Ryan, C., Berrow, S.D., Mchugh, B., O’Donnell, C., Trueman, C.N. \& O'Connor, I. 2014. Prey preferences of sympatric fin (Balaenoptera physalus) and humpback (Megaptera novaeangliae) whales revealed by stable isotope mixing models. Mar. Mammal. Sci. 30: 242-258.

Santos, R.A. \& Haimovici, M. 2001. Cephalopods in the diet of marine mammals stranded or incidentally caught along southeastern and southern Brazil (2134으). Fish. Res., 52: 99-112.

Seyboth, E., Botta, S. \& Secchi, E. 2017. Using chemical elements to the study of trophic and spatial ecology in marine mammals of the southwestern Atlantic Ocean. Advances in Marine Vertebrate Research in Latin America, 22: 221-248.

Schell, D.M., Saupe, S.M. \& Haubenstock, N. 1989a. Bowhead whale (Balaena mysticetus) growth and feeding as estimated by D13C techniques. Mar. Biol., 103: 433-443.

Schell, D.M., Saupe, S.M. \& Haubenstock, N. 1989b. Natural Isotope abundances in Bowhead Whale (Balaena mysticetus) baleen: markers of aging and habitat usage. In: Stable Isotopes in Ecological Research (eds) Rundel PW, Ehleringer JR, Nagy KA. p. 260-269.

Schell, D.M. 2001a. Carbon isotope ration variations in Bering Sea biota: The role of anthropogenic carbon dioxide. Limnol. Oceanogr., 46: 999-1000.

Schell, D.M. 2001b. Declining carrying capacity in the Bering Sea: Isotopic evidence from whale baleen. Limnol. Oceanogr., 45: 459-462.

Shoeninger, M.J. \& DeNiro, M.J. 1984. Nitrogen and carbon isotopic composition of bone collagen 
from marine and terrestrial animals. Geochimica et Cosmochimica Acta, 48: 625-639.

Thomas, P.O., Reeves, R.R. \& Brownell Jr., R.L. 2015. Status of the world's baleen whales. Mar. Mamm. Sci., 32: 683-734.

Todd, S., Ostrom, P., Lien, J. \& Abrajano, J. 1997. Use of biopsy samples of Humpback whale (Megaptera novaeangliae) skin for stable isotope (13C) determination. J. Northw. Atl. Fish. Sci., 22: 71-76.

Torres, L.G., Rayment, W., Olavarri C., Graham, B., Baker, C.S., Patenaude, N., ..., Carroll, E.L. 2016. Demography and ecology of southern right whales Eubalaena australis wintering at sub-Antarctic Campbell Island, New Zealand. Polar Biol., 40: 95-106.

Troina, G.C., Dehairs, F., Botta, S., Di Tullio, J.C., Elskens, M. \& Secchi, E.R. 2020. Zooplankton-based $\delta 13 \mathrm{C}$ and $\delta 15 \mathrm{~N}$ isoscapes from the outer continental shelf and slope in the subtropical western South Atlantic. Deep-Sea Research Part I., 159: 14p.

Valenzuela, L.O., Sironi, M., Rowntree, V.J. \& Seger, J. 2009. Isotopic and genetic evidence for culturally inherited site fidelity to feeding grounds in southern right whales (Eubalaena australis). Molecular Ecology, 18(5): 782-791.

Van de Vijver, K.I., Hoff, P.T., Das, K., Dongen, W.V., Esmans, E.L., Jauniax, T., Bouquegneau, J.M., Blust, R. \& De Coen, W. 2003. Perfluorinated Chemicals Infiltrate Ocean Waters: Link between Exposure Levels and Stabe Isotope Ratios In Marine Mammals. Envirn. Sci. Technol., 37: 5545-5550.

Vighi, M., Borrel, A., Crespo, E.A., Oliveira, L.R., Simões-Lopes, P.C., Flores, P.A.C., García, N.A. \& Aguilar, A. 2014. Stable isotopes indicate population structuring in the Southwest Atlantic Population of Right Whales (Eubalaena australis). Plos One, 9(3).

Vighi, M., Borrell, A. \& Aguilar, A. 2016. Stable isotope analysis and fin whale subpopulation structure in the eastern North Atlantic. Mar. Mammal Sci., 32: 535-551.

Weilgart, L.S. 2007. The impacts of anthropogenic ocean noise on cetaceans and implications for management. Canadian Journal of Zoology, 85(11): 1091-1116.

West, J.B., Bowen, G.J., Dawson, T.E. \& Tu, K.P. 2010. Isoscapes: understanding movement, pattern, and process on Earth through isotope mapping. New York: Springer.

Witteveen, B.H., Anthony, G., Worthy, J., Worthy, G.A.J. \& Roth, J.D. 2009a. Tracing migratory movements of breeding North Pacific humpback whales using stable isotope analysis Tracing migratory movements of breeding North Pacific humpback whales using stable isotope analysis. Mar. Ecol. Prog. Ser., 393: 173-183.

Witteveen, B., Worthy, G., Wynne, K. \& Roth, J. 2009b. Population structure of North Pacific humpback whales on their feeding grounds revealed by stable carbon and nitrogen isotope ratios. Mar. Ecol. Prog. Ser., 379: 299-310.

Witteveen, B.H., Worthy, G.A.J., Wynne, K.M., Hirons, A.C., Andrews, A.G. \& Markel, R.W. 2011. Trophic Levels of North Pacific Humpback Whales (Megaptera novaeangliae) Through Analysis of Stable Isotopes: Implications on Prey and Resource Quality. Aquatic Mammals, 37(2): 101-110.

Witteveen, B.H., Worthy, G.A.J., Foy, R.J. \& Wynne, K.M. 2012. Modeling the diet of humpback whales: An approach using stable carbon and nitrogen isotopes in a Bayesian mixing model. Mar. Mammal Sci., 28: 1-18.

Witteveen, B.H. \& Wyinne, K.M. 2016. Trophic niche partitioning and diet composition of sympatric fin (Balaenoptera physalus) and humpback whales (Megaptera novaeangliae) in the Gulf of Alaska revealed through stable isotope analysis. Mar. Mammal Sci., 32: 1319-1339.

Wood, S.N. 2006. Generalized additive models: an introduction. R. Chapman and Hall. 1st edn. CRC Press. Boca Raton, FL.

Wright, D.L., Witteveen, B., Wynne, K. \& HorstmannDehn, L. 2015. Evidence of two sub aggregations of humpback whales on the Kodiak, Alaska, feeding ground revealed from stable isotope analysis. Mar. Mammal Sci., 31(4): 1378-1400. 